Сања Ћ. Мацура

Универзитет у Бањој Луци

Филолошки факултет

Студијски програм српског

језика и књижевности

\title{
ФУНКЦИЈА ФОКАЛИЗОВАНЕ НАРАЦИЈЕ У ПРИПОВИЈЕЦИ „ЗЛОСТАВЉАЬЕ” И. АНДРИЋА
}

У приповијеткама Иве Андрића фокализована нарација има важну улогу у обликовању ликова. У овом раду предочавамо резултате анализе стилске функције наративног слоја перцепције, исказане кроз фокализацију, на примјеру приповијетке „Злостављање”. При томе указујемо на употребу „прозора фокализације” унутар „куће прозе” као важне компоненте основног обликотворног поступка у изградњи ликова. Неријетко су ликови носиоци али и објекти спецификоване перцепције, тј. носиоци су особина које их издвајају из друштвено устаљених оквира понашања и ситуирају насупрот оних ликова у којима се њихова различитост примарно огледа, иако су припадници истог микрохабитуса.

Клучне ријечи: прозор фокализације, нарација, лик, И. Андрић, „Зостављање”

1. У погледима на фокализацију ${ }^{1}$ заснованим на Женетовим промишљањима овога феномена, евидентно је да је она примарно сагледана као ограничење перспективе и оријентација наративне информације у односу на

* sanja.macura@flf.unibl.org

1 В. Вуловић 2015 и Мацура 2018а. 
неку (угл. је у питању лик) перцепцију, знање, тачку гледишта или имагинацију (в. Херман - Јан - Рајан 2008). Тако сваћена, теорија фокализације обухвата различите начине селектовања, уређивања и каналисања наративне информације, односно посебно виђење догађаја с неке тачке гледишта, без обзира на то колико то становиште било објективно (поуздано) или субјективно (непоуздано). Дио оваквог разумијевања фокализације је и сагледавање Женетове интерне фокализације као фокализације „кроз” лик, чиме се ум протагонисте посматра као прозор са кога се свијет перципира ${ }^{2}$. (Нидерхоф 2011) За Мике Бал нефокализованост није могућа ${ }^{3}$, те она издваја три елемента: визију, инстанцу која то види, и оно што се види, при чему је за њу фокализација „однос између презентованих елемената и визије кроз коју су они презентовани" (2000: 119), што у терминосистему ове теоретичарке условљава појаву нове групе појмова попут фокализатор (унутрашњи/интерни и спољашњи/ екстерни), фокализовано, нивои фокализације итд. Док за Женета „не постоји лик који фокализује [...], а реч фокализатор, под претпоставком да њоме некога и означимо, могла би се односити искључиво на онога ко фокализује приповедање, односно на приповедача, или - ако хоћемо да изађемо из конвенција фикције - на самог аутора који преноси или не преноси на приповедача своју моћ фокализовања" (1995: 82), Манфред

2 Умјесто размишљања о фокализацији као избору или фокусирању на одређену област (тачку) у свијету приче.

3 На трагу оваквог закључка су и посткласични наратолози, нпр. Дејвид Херман који констатује да се питањем перспективе теоретичари књижевности баве као скаларним, а не као бинарним феноменом, јер не постоји нешто као што је бесперспективна или неперспективна прича, већ само начини представљања наратива при чему је важност перспективе мање или више наглашена. (Херман 2002). 
Јан указује на два могућа питања: ко види? (ако било ко види) - фокални лик или хипотетички посматрач) и ко фокализује? (наратор или говорник) (1995: 245). Шломит Римон-Кенан (2007) покушала је да побољша и употпуни Женетову типологију, те се, полазећи од класификације Мике Бал, ослонила на подјелу на интерног и екстерног фокализатора и уз то истакла различите аспекте фокализације: опажајни (вид, слух, мирис), психолошки (који обухвата когнитивну и емоционалну компоненту) и идеолошки, наглашавајући да ако је фокализатор лик онда његово опажање припада причи, а ако је фокализатор сам наратор, онда фокализација постаје само једна од реторичких стратегија. У складу с тим је и Четменов став да „[К]оментари приповедача нису перцепције и концепције истог реда као перцепције и концепције лика", па их не треба с њима мијешати и бркати, јер „[У]потреба фокализације или ма ког јединственог термина да се означе посве различите функције које ликови и приповедачи обављају, нарушава дистинкцију између приче и дискурса" (1995: 89), што резултира његовим приједлогом два нова термина - slant (гледиште, аспект, тачка гледишта) и filter (филтер) зарад одвајања онога што представља ставове наратора од онога што припада лику у свијету приче (перцепција, когниција, ставови, осјећања, сјећања, имагинација). Нараторова улога није само „причање приче”, он „може расправљати о начину на који обликује свој текст, може 'ћаскати' са читаоцем, објашњавати поступке својих ликова, износити сопствени став (емоционални, интелектуални или морални) о различитим аспектима приповести, о ликовима или, како би рекао Форстер, о 'свемиру' уопште" (Marčetić 2003: 95). Оно што постженетовски наратолози називају активношћу приповједача-фокализатора заснива ce на женетовски схваћеним функцијама (примарна наративна, те метанаративна, комуникативна, тестимо- 
нијална и идеолошка као екстранаративне). Имајући на уму наведено, Манфред Јан предлаже прављење разлике између фактора фокализације који се тичу филтрирања перспективе и фактора фокализације који се тичу филтрирања информација и указује на кретање фокализације од зоне сигурности до зоне виртуелности и радикалне несигурности. (Херман - Јан - Рајан 2008: 175).

Ако је фокализатор лик а не наратор, онда он читаоцу догађаје презентује преко своје перцепције, емоција и когниције, тј. „он пружа читаоцу слику света наратива”. (Варвек - Херман 2004: 117). Из тог угла сагледана, фокализација је важан дио односа између наративног текста и његовог читаоца, јер текст усмјерава и утиче на читаочево очекивање подстичући га или га затомљујући. Читалац апсорбује доживљај ликова управо путем фокализације, те се кроз њу свијет наратива открива читаоцу.

У својој теорији фокализације (заснованој на тзв. прозорима фокализације - windows of focalization), Манфред Јан указује на Џејмсову метафору „прозора” као основног модела фокализације (на основу когниције и рецепције), а у складу с тим и на његову „кућу прозе” у којој су наратори „посматрачи” који стоје на прозорима куће, те је оно што наратори виде одређено бројним факторима: „обликом прозора (који могу бити само 'рупа у зиду'), погледом који се пружа са њега, инструментом који користи ('пар очију', 'двоглед')" (Јан 1996: 252), а првенствено свијешћу посматрача и његовом конструкцијом реалитета. Различити наратори ствари виде другачије, чак и када посматрају исто, па тако неко види црно тамо гдје други види бијело, у зависности од тога на шта се током гледања и посматрања усресређују (фокусирају) и од тога како виде то што посматрају. Тако лик догађаје види другачије него наратор, јер док наратор посматра с прозора који је смјештен на одређеној висини, лик 
догађаје види и сам се налазећи на позорници која је истовремено у видокругу наратора. Наратор који није лик рефлектује свијест свих осталих учесника на вишем нивоу, он постаје екран и функционише као прозор. Пошто је наратор приче „првенствено и њен читалац и слушалац", наратор и читалац постају уједињени посматрачи. (Јан 1996: 252) На основу Џејмсове метафоре прозора и теорије менталне слике оријентисане на читање, Јан је увео појам „прозор фокализације”. Прозори наративног текста имају широку лепезу могућности у односу на догађаје и актере приче, какви год типови ликова они били. Уз то, текст читаоца не снабдијева свим потребним информацијама потребним за интерпретацију, а сви текстови су пукотинасти („text do not supply all the information needed for their interpretation... all texts are gappy") (Сполски 2008: 193). Сматрајући да свака прича садржи онтолошке пукотине, Алан Палмер (2010) разликује привремене пукотине (њих читалац попуњава током читања) и сталне пуковине или бјелине - „temporary and permanent gaps or blanks”. Уз бјелине у тексту које читалац попуњава сам не прекидајући процес конкретизовања фикционалног свијета наратива (нпр. конкретизација изгледа и распореда намјештаја у простору у којем се догађај одиграва или изглед одјеће, облик фризуре, боја очију лика), постоје и скривени наративи („црне рупе”) који настају на мјестима бјелина које није могуће лако попунити без нарушавања континуалног конкретизовања фикционалног свијета наратива. На тим мјестима „прекида”, тј. бјелина које није могуће попунити у тексту и из текста, наратив почиње да значи нешто другачије за сваког читаоца, тј. у њему читалац ишчитава оно што није написано, оно што у њему не пише.

2. Андрићева приповијетка „Злостављање” (в. Мацура 2018), означена је екстерном нараторском позицијом. 
На првостепеној наративној позорници перцептивно доступној екстерном наратору налази се другостепена позорница перцептивно доступна ликовима чија опажања припадају сижеу (причи). Прозори фокализације су, стога, у првом случају ограничени нараторском реторичком стратегијом, а у другом различитим аспектима фокализације (у овом примјеру опажајним, когнитивним и емоционалним). На сижејном почетку налази се фабуларни завршетак, а нарација креће из ex post позиције. (в. Мацура 2012: 85) У уводном дијелу приповијетке, наратор предочава ситуацију која је у post factum фази епилог је ту, речено је све што се догодило. Аница је безразложно напустила мужа и њихов узоран, миран брак, при чему су је сви осудили, отац је одбио да је прими код себе, а брак је разведен на њену штету. Овај нараторов „извјештај” могао би да буде прихваћен као такав када у њему не би постојале двије индикативне синтагме - прва је да није било „видног ралога” за напуштање мужа, а друга је карактеризација Анице као „сироте самице” („За такав поступак није било видног разлога ни разумног оправдања, ни у њеном браку, који је био миран и узоран, ни у животу сироте самице који је водила после одласка из куће.", 111$).$ Из њих проистичу најмање два питања - ако није било „видног разлога”, да ли постоји разлог који је скривен од очију јавности и ако је Аница крива за развод, зашто је у нараторском коментару окарактерисана као „сирота самица”. Прва бјелина, она коју чини непостојање индикација за Аничино напуштање мужа, привременог је карактера. ${ }^{5}$ Могућност њеног попуња-

4 Сви наводи из извора дати су према издању, па наводимо само број странице у загради.

5 На основну могућност попуњавања ове пукотине понајбоље је указао сам аутор: „Имам осећај - вели Андрић - да су критичари једнострани у оцени ове приповетке. Безмало сви истичу како сам ја ту бранио жену и заузимао се за њен положај. 
вања лежи у познатом нагађању о томе „шта се збива између нечија четири зида”, а тиче се велике разлике у годинама између супружника - читалац ће лако при конкретизовању фикционалног свијета закључити да је млада жена из очигледног разлога напустила много старијег мужа. Али, друго питање које се јавља пред читаоцем, оно које се тиче нараторског коментара о „сиротој самици”, функционише се као „пукотина”, бјелина коју није могуће попунити ако је прва бјелина попуњена на наведени начин. Жена која због потраге за партнером напушта свог старијег мужа свакако не заслужује квалификацију „сирота самица”. Том диспаритету могућих попуна ове двије бјелине доприноси и нараторов коментар: „Када се каже какав је био тај брак, одмах ће се разумети зашто је опште мишљење било против жене." (112) Овај коментар увод је у нараторов опис ликова Анице и газда Андрије, јер „опште мишљење” почива на неписаним правилима живота вароши и функционисања свих њених сегмената која прописују образац за понашање и од којих не смије да буде одступања, јер би, у супротном, услиједила синхронизована активност друштва на санкционисању преступнице. Дакле, након вишеструког указивања на немогућност сагледавања позадине и разлога за Аничино напуштање мужа, слиједи паралелни опис њих обоје, дат кроз контрастну пројекцију поређења тога ко је и какав је газда Андрија, те ко је и каква је Аница. При томе оно што наратор као информацију предочава читаоцу није идентично ономе што наратор „зна”. Наративна информација коју наратор предочава читаоцу је манипулативног типа и удаљава га од правих одговора који би могли да попуне бјелине. Газда Андрија је посједник фабрике четака, давно

Није реч о томе. Жена је у овој приповеци нормална особа, а присиљена је да напусти свирепог мужа који је за свет око ње сасвим 'нормалан' и 'виђен' човек. Јер, тај свет каже: 'Оставила онаквог мужа."' (Јандрић 1982: 125-126) 
је прешао четрдесету, никада се није женио, све што има постигао је сам „својим радом, својом штедњом и скромношћу”, стекао је „имање, радњу и положај”. (112) Аница је „сирота девојка”, најстарије дијете у вишечланој породици која је остала без мајке, све обавезе су на њеним плећима, уз то је стасита и снажна, млада, „једна од оних ретких жена које умеју да буду корисне без речи, које не траже подстрека у признању, не узимају после сваког напора маску мученице, и које у свему изгледају довољне саме себи... њена вредноћа и њена снажна, скривана лепота замакле су за око газда-Андрији”, јер била је „лепа, крупна, чедна и послушна девојка. Утолико боље што је сирота.” (113) Док је газда Андрија „у свему одмерен и разложан” (115), Аница је „ћутљива, скромна а увек једнака”. (116) Са свог повлаштеног мјеста, посматрајући првостепену позорницу, наратор је у прилици да види све. Али, он селективним, усмјераваним информацијама читаоцу предочава само позитивне особине ликова, на тај начин га удаљавајући од истине о узроцима пропасти њиховог брака. Томе доприносе и његови коментари - „Ни по чему тај брак није одударао од осталих, ако не по својој тихој сређености и непоремећеном складу” (115). Ни то што нису имали дјеце „није могло да поремети савршенство овога брака. Све је ишло како бог заповеда и како свет замишља и очекује... Он је био добро примљен и цењен међу људима... Она је водила ону велику кућу у потпуном споразуму с мужем." (115) Читалачка запитаност о разлозима за Аничино напуштање мужа која је постигнута већ првим реченицама ове приповијетке дуго нараста, јер су описи ликова Анице и Андрије те њиховог брака изразито афирмативни. Дескрипција почива на низању догађајности које нуде опис супружничког међуодноса и њихових претпостављених карактера.

Заокрет (plot twist) у сижеу наступа трансфером фокализације са првостепене на другостепену позор- 
ницу. Док год читалац о ликовима сазнаје само кроз перспективу наратора, не назире „пукотине” у њиховом међуодносу. Када фокус нарације бива премјештен у ликове, превасходно у газда Андрију, он престаје да буде опажајни и постаје психолошки, превасходно базиран на когнитивној и емоционалној компоненти. Кроз комбиновање увида у првостепену и другостепену позорницу, готово неосјетно, примаран постаје индикативни однос газда Андрије према Аници - он увиђа да „добра жена заиста нема цене” (116), да је она сва његова и ничија више, „од косе па до ножних прстију”. (117) Промјена обојености фокализоване нарације повезана је с итерацијом којом су „покривене” све ситуације у којима газда Андрија пред другима употребљава лексему „жена” или синтагму „моја жена”. Ово исказивање његовог дословно власничког односа према супрузи мијења видокруг с прозора фокализације, с којег бива „уклоњен” оквир идиличности уступивши мјесто оквиру реалности. Интерлудиј у овај заокрет је нараторов коментар антиципативног карактера - „Од тог осећања среће шире се димензије сопствене личности у бескрај.” (117) Тај „бескрај” може да буде у вези са развијањем и напредовањем његове личности, али може да буде у питању и другачија врста бескраја, која има везе с тим да је код њега све „било савршено, осим његовог спољног изгледа" (117), јер он „истина, није био никад наочит ни леп човек, али није био ни без достојанства и држања”. (112) У Андрићевим приповијеткама често се наилази на „у основи (само) разорну и опсесивну страну људске природе као оно што заправо влада постојањем појединаца" (Брајовић 2015: 10), а газда Андријиним постојањем овладало је потпуно осјећање среће због постигнуте савршености живота. „Имагинација као уточиште и као мучилиште ево обрасца који, чини се, своје важење показује безмало свуда где распознајемо андрићевски обликоване јунаке 
и андрићевски успостављене констелације приватних порива и склоности с јавним пословима и збивањима." (Брајовић 2015: 139) Управо се у зони те и такве имагинације одвија заокрет у обојености нарације, а фокализација се премијешта на другостепену позорницу, при чему њени прозори бивају оивичени тако да код Анице преовладава когниција а код газда Андрије виртуелни наратив. ${ }^{6}$ До тада перципиран и презентован у позитивном свјетлу, газда Андрија од тренутка у којем супругу почне да сагледава као своје власништво бива презентован као „савршен тип ружног човека”, који „ни у колевци није био леп, а доцнији га је живот дотеривао на чудан калуп". (117) На тај начин се пред читаоцем отвара до тада непримјећена бјелина чије су димензије знатне, јер већ успостављено континуално конкретизовање фикционалног свијета наратива бива нарушено и „избачено” из већ успостављеног колосјека. Детаљан опис бројних газда Андријиних крупних физичких мана наводи читаоца на помисао да су можда оне проузроковале то да га Аница напусти. Само, ако је то тако, како је онда могуће да се Аница након удаје „одмах у почетку ослободила и пролепшала. Њена лепота је сада долазила до свога правог израза... Развезала се њена снага"? (116) С обзиром на то да указивање на утицај који је брак имао на Аницу сижејно претходи истицању газда Андријиних физичких мана, читаочева тежња ка антиципацији спречава да буде наведен на погрешан закључак. Јер, да је код Анице постојала згроженост мужевљевим физичким изгледом, она би се била јавила током првих брачних дана (и ноћи), те би млада жена копнила и изгледала несрећно.

Дакле, ни његов физички изглед, ни његове године нису проузроковале да га Аница напусти. Бјелина која стоји пред читаоцем од почетка сижеа овим постаје све

6 О виртуелном наративу в. Милосављевић Милић 2016. 
већа. Да би била „испуњена” садржајем који би могао да се укључи у већ постојеће читаочево конкретизовање фикционалног свијета наратива, он мора да буде дат „изнутра”, мора у себе да укључи само другостепену позорницу на којој се као објекат фокализације налази газда Андрија, а основни фокализатор је Аница, при чему прозор њене фокализације не може да буде лишен емотивне компоненте. „Спуштање” погледа са првостепене позорнице није драстично и његов интензитет је субординиран нараторској екстерној позицији. До њега долази постепено, прво указивањем на то да је газда Андрија „први пут откад зна за себе почео да се бави самим собом, да се мери, оцењује, испитује и упоређује”. (119) „Присуство једног бића које ћути или повлађује, а пред којим се не мора уздржавати и снебивати" (119), и које при томе сматра својином, покренуло је у газда Андрији процес самофокализације, односно он почиње да види „сам себе, шта је и ко је, какав је и колики је, шта све зна и уме, може и сме”. (119) Унутар њега долази до удвајања личности у газда Андрију дању, у јавности и газда Андрију ноћу, у кући. Један Андрија остаје савршено углађен, комуникативан, вјеран свом већ познатом „начину” опхођења са свима који је његово дистинктивно обиљежје, а други Андрија се изобличава у чудовишног мучитеља своје младе супруге ${ }^{7}$.

Начин на који газда Андрија мучи Аницу посебног је типа. Базиран је на виртуелном наративу и кроз њега се идентитет лика газда Андрије изграђује не на оном што јесте, већ на ономе што није, дакле на својеврсном пољу празнине. Заснован је на нереализованој могућности која би требало да почива на дистинктивној бинарној опозицији актуално - могуће, али умјесто тога почива на опозицији реално - пројектовано, при чему је реално

7 О теми злостављања у овој приповијеци в. Мацура 2018. 
све оно што чини газда Андријин активитет у друштву и пред очима јавности, а пројектовано је оно што из њега покуља далеко од очију јавности, под нијемим и згађеним погледом његове супруге. Почетна форма мучења у тексту је исказана итерацијом - оно што се дешава више пута дато је у тексту једном, репрезентативно. Означено је фреквентном употребом лексеме „разумеш”, коју газда Андрија понавља Аници у значењу „ти ништа не разумијеш”, при томе је називајући „моја луда главо” (119). Ова итерација осликава његов аутоимаж у којем је садржан како његов однос према њој, оној која не може ништа да разумије, тако и себи самом, јер иако аутоимаж подразумијева слику о себи, у овом случају та слика о себи (газда Андријина) је неразлучиви дио бинарног пара којем припада и слика о сопственој жени (Аници). Колико год у његовој интерпретацији догађаја она ништа не разумије, толико он више може, вриједи, смије.

Газда Андријин прозор фокализације је вишеслојан, јер поглед на виртуелног себе подразумијева истовремени претпостављени или подразумијевани поглед Анице која је слушалац попут рупе „у црној земљи” (119). Његов аутоимаж није функционалан без те друге компоненте, без претпостављеног начина на који га она види и слуша. Њен прозор фокализације на тај начин бива удвојен. Један је онај који претпоставља газда Андрија и у њему он је очаран, занесен, жели да је изненади и збуни, он је у свом виртуелном свијету којем не свједочи нико осим ње и управник вароши и први краљев сарадник с неограниченим овлашћењима. Други је онај који читаоцу предочава наратор и у њему је газда Андрија за Аницу „непозната личност” (121) која се пред њеним очима надима и бљешти, гротескна фигура која устаје, глуми, мијења регистар стилова и начина опхођења с виртуализованим ликовима из сопствених измишљених свјетова. Док говори Аници као слушаоцу, газда Андрија 
је уопште не гледа, не види. Оно што он види је сопствени одраз у њеним очима и при томе „потпуно заборавља на њу” (121). Али, у њеним „хладним модрим очима” нема његовог одраза, јер Аница га гледа „право у лице, не у очи него у лице”. (121) На другостепену позорницу отворена су два прозора фокализације. На једном се налази газда Андрија, а на другом је Аница. Прозор газда Андрије има посебност што кроз њега он посматра самог себе ситуираног у виртуелни хронотоп. Саставни дио те фокализације у којој су њен субјекат и објекат исти јесте и његова визија Аничине перспективе. У тој визији, Аница клима главом, покорно и нијемо слуша и гледа, очаравајући га својим бескрајним ћутањем и пасивним учешћем који га додатно стимулишу. Тој газда Андријиној слици Аничине слике њега супротстављена је њена стварна перцепција његових вечерњих „наступа”. Кроз свој прозор фокализације, Аница газда Андрију гледа збуњена његовим новим начином причања, који је био „толико опречан са његовим говором и понашањем преко дана, на послу и у друштву” (121), згрожена новооткривеним мрачним дијелом његове личности испуњене немилосрдношћу, бешћудношћу и суровошћу од којих Аницу хвата језа. Кроз монологе који се понављају из вечери у вече постајући неизбјежни ритуал у којем газда Андријино себељубље поприма виртуелно вербално обличје, њен прозор фокализације бива додатно условљен когницијом и емоцијом. То посебно долази до изражаја када његове приче уђу у зону виртуелизације властите сексуалности, у којој је, наравно, као и у свему другом далеко изнад свих оних с којима се пореди, како по броју жена које су га жељеле, тако и по „начину” на који је рјешавао немиле ситуације. Ту попуштају сви до тада постојећи обзири, норме и скрупуле, а Аница га слуша и „гледа са хладним запрепашћењем у себи”. (124) Када повеже оно што проживљава са причама које је чула о настраним 
мушкарцима „који имају болесне прохтеве и који траже од жена недостојне и неприродне ствари" (130), њен страх и запрепаштеност претварају се у гађење и свијест о томе „да се њена мука не може никоме ни наговестити, а камоли казати, и према томе да јој нема ни лека”. (139) Преузимајући улогу фокализатора, наратор дотадашње именовање Андрије као газде трансформише у „четкар”. Ова лексичка деградација с „газде” на „четкара” не губи се до краја приповијетке. Комплементарно с њом долази контрастирање Андријиног и Аничиног изгледа, наговијештеног али субмисивног све до овога тренутка у сижеу: „жена сам имао тада на сваки прст по три. И човек показује своје велике, чворновате прсте жени поред себе. Лепа, бујна, двадесет година млађа и за две главе виша од њега, она их гледа са хладним запрепашћењем у себи." (124) Та диспропорција додатно је апострофирана гротескном сценом ритуала његовог спремања у кревет који понавља као „неку литургију у част самом себи”. (134) Било је могуће овај опис дати и кроз Аничин прозор фокализације, али је умјесто тога он дат кроз нараторов прозор, што је омогућило инкорпорирање његових додатних коментара који у супротном не би били могући. Он „[С] кида зубе са горње вилице, чисти их нарочитом четком и оставља у чашу воде. Испира грло нарочитом водицом, увлачи у нос фитиље натопљене машћу и перуанским балсамом, меће памук у лево ухо (само у лево, јер на десном спава)”. Облачи „преко тога кошуљу, спаваћицу; кошуља је најнижа мушка нумера што постоји, па ипак је она малом човеку до земље. На своје ћелаво теме четкар меће нарочиту капу од беле вуне [...] угаси лампу и, окренувши жени леђа, заспи одједном, као животиња”. (124-125) Тренутак његовог заспивања почетак је њене слободе. Граница између те слободе и неслободе је њен кревет, који функционише као хронотоп мира и тишине. Али, четкар прелази границу, искорачује из свог и улази у њен простор, јер 
након неког времена не престаје да прича када она легне у кревет и склопи очи правећи се да спава, него сједа на њен кревет и наставља да прича. Аница „се осећа као створење које злоупотребљавају, злостављају на бездушан, подмукао, а привидно безазлен и допуштен начин”. (130)

Како четкар нарушава границу њеног повлаштеног простора и почне да сједа на руб њеног кревета непрекидно причајући, нараста и степен опсцености садржаја његових монолога, а истовремено нестаје њено посљедње уточиште. Иако физички надмоћна, она се осјећа субординирано, а њен отпор који се састојао у томе да не гледа у мужа него поред њега и да се претвара да је заспала при самом лијегању у кревет, престаје да буде функционалан. Њена перцепција властите позиције усовљена је неписаном обавезом да испуни „захтеве [...] чаршијског полиса у чијем [...] окриљу се по правилу одигравају индивидуалне драме Андрићевих јунака." (Брајовић 2015: 170)

Преломни тренутак у којем напушта кућу и мужа не рекавши никада и никоме који је разлог за то резултат је кумулативног незадовољства. Повод је баналан - од момка из радње који је дошао по нешто помислила је да је њен муж и након тога није имала снаге да чека и још једном у том истом дану проживи мужевљев повратак с посла, јер „године би прошле; ако не би подлегла, она би их претурила, све ћутке; претурила би године, али није могла да претури сате и минуте”. (139)

3. Бјелина с почетка сижеа тек на његовом крају бива потпуно испуњена. Разлог због којег је каснија „сирота самица" напустила кућу и мужа постаје познат читаоцу. Пошто је исприповиједана из екстерне нараторске позиције, ова приповијетка нуди мноштво нараторских коментара који надрастају перспективу и унутрашњи свијет ликова. Ипак, првостепена позорница није изразито доминантна, јер је перспектива ликова остала сре- 
дишњи дио структуре и текстуре наративног текста. Његово тежиште је на аутоимажу газда Андрије ситуираном у виртуелном наративу, али тако да би био обесмишљен или чак не би ни постојао да његов интегрални дио није Аничина перцепција коју он претпоставља, а која је у реалном наративу супротна. Колико је у приповијеци „Злостављање” плодотворно комбиновање двостепености позорнице и укрштање прозора фокализације екстерног наратора са прозорима фокализације ликова понајбоље се види у њеној екранизацији ${ }^{8}$ у којој је начињена измјена, јер је наративни глас дат ликовима, газда Андрији и Аници. На тај начин је изгубљена могућност наднаративног преношења нараторских коментара. Везивање нарације за ликове поједноставило је слојевитост и комплексност нарастања виртуелног наратива као основног средства у формирању паралелних секундарних фабула унутар примарне фабуле. Док је у приповијеци злостављање Анице уткано у вербални свијет и не постоји физичка агресија газда Андрије према Аници, у драматизацији се налазе сцене у којима он ставља руке око Аничиног врата, насрће на њу, чак посеже и за ножем у жару причања, те она не само да се гуши у гађењу према новооткривеном унутрашњем свијету свога мужа, него сасвим оправдано стријепи за свој живот. Тиме је нарушен основни оквир типа приказаног мучења жене као и Аничине реакције на њега, што помјера основну осу приповијетке, али и зорно показује колике су важност и улога вишеслојне фокализоване нарације у овој Андрићевој приповијеци, јер је управо њиховим изостанком у потпуности нарушена основна значењска нит која чини основу њеног текстума.

8 Екранизација је настала на основу драматизације Петра Зеца, а у њој играју Александар Берчек и Весна Тривалић. („Злостављање” - ТВ драма, адаптација истоимене приповијетке И. Андрића, емитована на PТC-y, 14 марта 2012.) https:/www.youtube.com/ watch?v=_cQlu8cQKE4 


\section{Литература}

Андрић 1984: I. Andrić. Zlostavljanje u: Znakovi, Sabrana dela Ive Andrića, dopunjeno izdanje, knj. 8, Sarajevo, 111-141

Бал 1995: M. Bal, Naracija i fokalizacija (Prilog teoriji pripovednih instanci). Reč 8, 71-85.

Бал 2000: M. Bal, Naratologija. Beograd: Narodna knjiga

Брајовић 2015: T. Brajović, Groznica i podvig. Ogledi o erotskoj imaginaciji i književnom delu Ive Andrića, Beograd: Geopoetika Варвек - Херман 2004: B. Vervaeck, L. Herman, Focalization between classical and postclassical narratology, The dynamics of narrative form: studies in Anglo-American narratology, John Pier (ed.). Berlin: Walter de Gruyter GmbH and Co, 115-138. $<$ http://books.google.rs/books?id=13aTiNOZPygC\&printsec $=$ frontcover\&hl=sr\&source $=$ gbs_ge_summary_r\&cad $=0 \# \mathrm{v}=$ on epage\&q\&f=false $>$ (приступљено 2. 5. 2017.)

Вуловић 2015: J. В. Вуловић, После Женета: фокализација у очима посткласичне наратологије, 3борник Матище српске за књижевност и језик, књ. 63, св. 2, 533-551.

Едмистон 1995: V.F. Edmiston, Fokalizacija i pripovedač u prvom licu: jedna revizija teorije, $\operatorname{Rec}$, 8, 95-101.

Женет 1980: G. Genette, Narrative Discourse: An Essay in Method. Trans. Jane E. Lewin. Oxford: Oxford University Press, $<$ https://archive.org/details/NarrativeDiscourseAnEssayInMet hod> (приступљено 12. 8. 2013.)

Женет 1988: G. Genette, Narrative Discourse Revisited. New York: Cornell Univesity Press, <http://books.google.rs/ books?id=RBK2NOMAbasC\&printsec $=$ frontcover $\&$ hl $=$ sr\&source $=$ gbs ge summary $r \& c a d=0 \# v=$ onepage $\& q \& f=f$ alse > (приступљено 9. 9. 2013.)

Женет 1995: Ž. Ženet, Perspektiva i fokalizacije. Reč, II/8, 81-84. „Злостављање” - ТВ драма, адаптација истоимене приповијетке И. Андрића, емитована на РТС-у, 14 марта 2012. Драматизација Петар Зец; играју Александар Берчек и Весна Тривалић https://www.youtube.com/watch?v=_cQlu8cQKE4

Јан 1996: M. Jahn, Windows of Focalization: Deconstructing and Reconstructing a Narratological Concept, Style, 30, 241-67. 
<http://www.uni-koeln.de/ ame02/jahn_1996.pdf> (приступљено 15.10.2016.)

Јан 1999: M. Jahn, More Aspects of Focalisation: Refinements and Applications, GRAAT: Publication des Groupes de Recherches Anglo-Américaines de l'Université François Rabelais de Tours, 21, 85-110. <http://www.uni-koeln.de/ ame02/jahn99b.htm> (приступљено 4.11.2016.)

Јан 2005: M. Jahn, Narratology: A Guide to the Theory of Narrative, English Department, University of Cologne, <http://www.unikoeln.de/ ame02/pppn.htm> (приступљено 1.5. 2015.)

Јандрић 1982: Lj. Jandrić, Sa Ivom Andrićem, drugo prošireno i dopunjeno izdanje, Sarajevo: Veselin Masleša

Марчетић 2003: A. Marčetić, Figure pripovedanja. Beograd: Narodna knjiga - Alfa

Мацура 2018: С. Мацура, (Не)пристајање на злостављање, у: А. Вранеш (ред.), Иво Андрић у нашем времену, Андрићград: Андрићев институт, 97-114.

Мацура 2018а: С. Мацура, Наративни лавиринт - Улазак, друго допуњено и измијењено издање, Бања Лука: НУБРС

Милосављевић Милић 2016: S. Milosavljević Milić, Virtuelni narativ - Ogledi iz kognitivne naratologije, Niš - Novi Sad: Filozofski fakultet - Izdavačka knjižarnica Zorana Stojanovića Нидерхоф 2011: B. Niederhoff, Focalization, The Living Handbook of Narratology. Interdisciplinary Center for Narratology, University of Hamburg, <http://wikis.sub.uni-hamburg.de/ lhn/index.php/Focalization> (приступљено 1.7.2016.)

Палмер 2010: A. Palmer, Large Intermental Units, Middlemarch. Postclassical Narratology, Approaches and Analyses, Jan Alber, Monika Fludernik (ed.), The Ohio State University Press, 83-104.

Принс 2001: G. Prince, A Point of View on Point of View or Refocusing Focalization, New Perspectives on Narrative Perspective, W. van Peer \& S. Chatman (eds), Albany: SUNY, 43-50.

Римон Кенан 2007: Š. Rimon-Kenan, Narativna proza, Beograd: Narodna knjiga - Alfa

Ричардсон 2009: B. Richardson, Plural Focalization, Singular 
Voices: Wandering Perspectives in "We"-Narration, Point of View, Perspective, and Focalization, P. Hühn, W. Schmid, J. Schönert (eds), Berlin - New York: Walter de Gruyter, 143159. <http://f3.tiera.ru/1/genesis/645-649/645000/cba572d26b 98f7682fb4bdc6751f0fc9> (приступљено 2.10.2016.)

Сполски 2008: E. Spolsky, Gapping, Routledge Encyclopedia of Narrative Theory, London and New York: Routledge, 193.

Херман 2002: D. Herman, Story Logic: Problems and Possibilities of Narrative. Lincoln: University of Nebraska

Херман 2009: D. Herman, Beyond Voice and Vision: Cognitive Grammar and Focalization Theory. Point of View, Perspective, and Focalization Peter Hühn, Wolf Schmid and Jörg Schönert (eds). Berlin - New York: Walter de Gruyter, 143-159.

$<$ http://f3.tiera.ru/1/genesis/645-649/645000/cba572d26b98f7682f b4bdc6751f0fc9> (приступљено 2.12.2016.)

Херман 2011: D. Herman, Inroduction. The Emergence of Mind: Representations of Consciousness in Narrative Discourses in English. Lincoln: Univ. of Nebraska Press, 1-41.

Херман - Јан - Рајан 2008: D. Herman, M. Jahn, M.L. Ryan, Routledge Encyclopedia of Narrative Theory, London - New York: Routledge

Четмен 1978: S. Chatman, Story and Discourse: Narrative Structure in Fiction and Film. Ithaca: Cornell University Press.

$<$ http://archive.org/stream/StoryAndDiscourseNarrativeS tructureInFictionAndFilm/chatman.seymour story.and. discourse narrative.structure.in.fiction.and.film1\#page/ n71/mode/2up > (приступљено 1.11.2017.)

Четмен 1995: S. Četmen, Likovi i pripovedači: filter, centar, sklonost i fokus interesa. Reč 8, 87-94. 
Sanja Đ. Macura

\section{THE FUNCTION OF FOCALIYED NARRATION IN I. ANDRIC’S NOVEL “ZLOSTAVLJANJE”}

Focalized narration has an important role in Ivo Andric's novels in regard to characterization. This paper presents results of analyze of stylistic function of the perception in narrative presented by focalization, with Andric's novel "Zlostavljanje" ("Molesting") as a case study. We emphasize usage of "windows of focalization" within "a house of fiction" as an important component of the primary procedure in the formation and characterization of characters. Often, characters are carriers but also objects of specified perception, i.e. they have characteristics which separates them from socially favored and welcomed frames of behavior and situates them opposite to characters their difference is primarily reflected in, although they belong to different micro locations. Narrator is in external position which enables a diversity of narrator's comments. Those comments are superior over the characters. Two main characters, Andrija and Anica have their own windows of focalization. Andria's window is determined by his self-image which is defined by Anica's obedience and silence while he enters virtual narratives as a full presentation of himself.

Key words: window of focalization, narration, character, I. Andric, "Molesting" 